\title{
Therapeutic potential of pravastatin for random skin flaps necrosis: involvement of promoting angiogenesis and inhibiting apoptosis and oxidative stress [Corrigendum]
}

\author{
Lin J, Jia C, Wang Y, et al Drug Des Devel Ther. \\ The authors apologize for this oversight as Dr Chen does \\ 2019;13:1461-1472 \\ not belong to affiliation 3 .
}

On page 1461, Dr Yijie Chen's name should read from Yijie $\mathrm{Chen}^{3,7}$ to Yijie Chen ${ }^{7}$.

\section{Publish your work in this journal}

Drug Design, Development and Therapy is an international, peerreviewed open-access journal that spans the spectrum of drug design and development through to clinical applications. Clinical outcomes, patient safety, and programs for the development and effective, safe, and sustained use of medicines are a feature of the journal, which has also been accepted for indexing on PubMed Central. The manuscript management system is completely online and includes a very quick and fair peer-review system, which is all easy to use. Visit http://www. dovepress.com/testimonials.php to read real quotes from published authors. 